\title{
Mitochondrial DNA signatures of restricted gene flow within divergent lineages of an atyid shrimp (Paratya australiensis)
}

\author{
AM Baker ${ }^{1}$, DA Hurwood ${ }^{2}$, M Krogh $^{3}$ and JM Hughes ${ }^{1}$ \\ ${ }^{1}$ Cooperative Research Centre for Freshwater Ecology, Centre for Riverine Landscapes, Griffith University, Nathan Campus, Queensland \\ 4111, Australia; ${ }^{2}$ School of Natural Resource Sciences, Queensland University of Technology, Brisbane, Gardens Point Campus, GPO \\ Box 2434, Brisbane, Queensland 4001, Australia; ${ }^{3}$ Sydney Catchment Authority, PO Box 50, Appin, New South Wales 2560, Australia
}

We measured spatial genetic structure within three previously described mitochondrial lineages of the atyid shrimp, Paratya australiensis, occurring in upland streams of two major catchments within the Sydney Water Supply Catchment, New South Wales, Australia. In all three lineages, there was significant spatial structuring of genetic variation between catchments. In two lineages, recurrent but restricted maternal gene flow has apparently predominated in shaping within-catchment genetic structure, although this framework may be overlaid with episodic contiguous/long-distance expansion events. In the third lineage, there was no evidence of spatial genetic structuring within one of the catchments, because one haplotype was both common and widespread throughout the sampled area. High-frequency haplotypes were also shared among subcatchments in the other two lineages, and we discuss both historical and contemporary processes that may have left these genetic signatures. Our results are generally concordant with previous reports of significant population structuring in $P$. australiensis, occurring in upland river reaches elsewhere in eastern Australia. We propose that restricted dispersal and gene flow among upland populations of $P$. australiensis is linked to dramatic architectural structuring within and among mountain streams. Heredity (2004) 93, 196-207, advance online publication, 23 June 2004; doi:10.1038/sj.hdy.6800493

Keywords: gene flow; mtDNA; dispersal; Paratya australiensis; Atyidae

\section{Introduction}

Recently, genetic techniques have been used to infer past and present patterns of dispersal in a range of aquatic species. Generally, it appears that, for groups such as insects possessing a flying stage within their life history, dispersal is widespread within and between drainages (eg Schmidt et al, 1995; Hughes et al, 1998; Miller et al, 2002), although there are exceptions such as blepheracerid midges, which show very restricted dispersal patterns even among streams in the same subcatchment (Wishart and Hughes, 2003).

For species whose entire life cycle is spent in the stream, however, dispersal is expected to be more restricted and to reflect the arrangement of stream channels. The Stream Hierarchy Model predicts that populations from the same stream will be more similar to one another than to populations from different streams in the same subcatchment, and populations from different subcatchments in the same drainage will be more similar to one another than to those from other drainages (Meffe and Vrijenhoek, 1988). Although

Correspondence: AM Baker, School of Natural Resource Sciences, Queensland University of Technology, GPO Box 2434 Brisbane, Queensland 4001, Australia.

E-mail: A.baker@griffith.edu.au

Received 20 April 2003; accepted 31 March 2004; published online 23 June 2004 genetic variation in many aquatic species does appear to fit the stream hierarchy model (eg the freshwater prawn Macrobrachium australiense, Cook et al, 2002; the pacific blue-eye Pseudomugil signifera, McGlashan et al, 2001), there seem to be as many instances where this is not the case (eg the zebra shrimp Caridina zebra, Hurwood and Hughes, 2001; the purple-spotted gudgeon Mogurnda mogurnda, Hurwood and Hughes, 1998; the empire gudgeon Hypseleotris compressa, McGlashan and Hughes, 2001). One explanation for these anomalies is that drainage rearrangements have occurred in recent geological time, and current genetic patterns reflect the structure of past, rather than present stream architecture (Hurwood and Hughes, 1998). However, an alternative explanation is that dispersal is not entirely restricted to the stream and occurs between estuaries during floods (H. compressa) or over land (C. zebra).

The atyid shrimp genus Paratya is represented by a single recognised species in Australia, P. australiensis. This species has been predicted to have a high dispersal ability due to: (a) wide distribution in upland and lowland streams and nonflowing freshwaters throughout several thousand kilometres of Australia's east coast (Williams, 1977), (b) the presence of all life stages in estuaries of southern Victoria (Walsh and Mitchell, 1995) and (c) larvae that may remain in the plankton for up to 45 days (Walsh, 1993). A number of genetic studies conducted on P. australiensis populations in the last 10 years, however, have progressed towards a clearer 
understanding of both the species' dispersal capability and taxonomic status.

Hughes et al (1995) examined spatial genetic (allozyme) structure within P. australiensis in upland streams of the Conondale Range, south-east Queensland, Australia. They found evidence of extremely limited movement on a small spatial scale. A subsequent study conducted in the same area by Hurwood et al (2003) using mitochondrial DNA found an even stronger pattern of restricted dispersal. They found instances of fixed haplotype differences between streams from the same subcatchment, and concluded that there was almost no contemporary dispersal among the sampled populations. Although there were shared haplotypes both within and between river drainages, these were interior (ancestral) nodes within the hypothesised network and deemed likely to be associated with historical gene flow processes.

Hurwood et al (2003) also discovered two deep (approximately 6\%) divergent mitochondrial lineages within different subcatchments of the Brisbane River Catchment. A parallel study by Hughes et al (2003) showed that where individuals of the two lineages were mixed, one lineage became extinct in approximately seven generations, possibly as a result of both asymmetrical mating and unviable crosses. Thus, an interdrainage transfer of one lineage from the Mary River Catchment south into one branch of the Brisbane River Catchment has probably resulted in the extinction of the resident lineage from a region of the stream.

In a recent phylogenetic study, Cook et al (in review) extended the geographic scope of the previous research by sampling $P$. australiensis from 34 river catchments, encompassing almost the entire latitudinal range of the species in mainland Australia. They reported the existence of 16 highly (approximately 2-9\%) divergent mitochondrial lineages of $P$. australiensis (designated A-P), which were hypothesised to form a component of a young cryptic species group of Pliocene origin.

A number of the divergent lineages are apparently restricted to relatively small geographic areas and, conceivably, these taxa have evolved different life histories and possess differing dispersal characteristics. If this is true, the extent of population genetic structuring within these lineages may differ. In the present study, therefore, we aimed to test whether three of these lineages (A, B and C) occurring in upland streams of south-east New South Wales exhibit similar matriarchal genetic structures, and from these data infer and contrast patterns of dispersal. One of these taxa (lineage A) is apparently restricted to the present study area and we were particularly interested in comparing population genetic structure and inferred dispersal behaviour of this lineage with (a) more geographically widespread lineages (B and $C)$ that occur in our study area and (b) Queensland populations of lineage $\mathrm{B}$ and lineage $\mathrm{E}$ (also widespread) studied by Hurwood et al (2003).

\section{Materials and methods}

\section{Study area and sampling}

The Sydney Water Supply Catchment (SWSC) is a network delivery system drawing water from three catchments in south-east New South Wales, Australia: The Hawkesbury/Nepean, Georges and Shoalhaven (Figure 1). The Hawkesbury/Nepean Catchment covers more than $20000 \mathrm{~km}^{2}$ to the south-west, west and north of Sydney, draining into the sea north of Sydney at Broken Bay. The Georges Catchment covers approximately $100 \mathrm{~km}^{2}$ and flows into the sea south of Sydney,

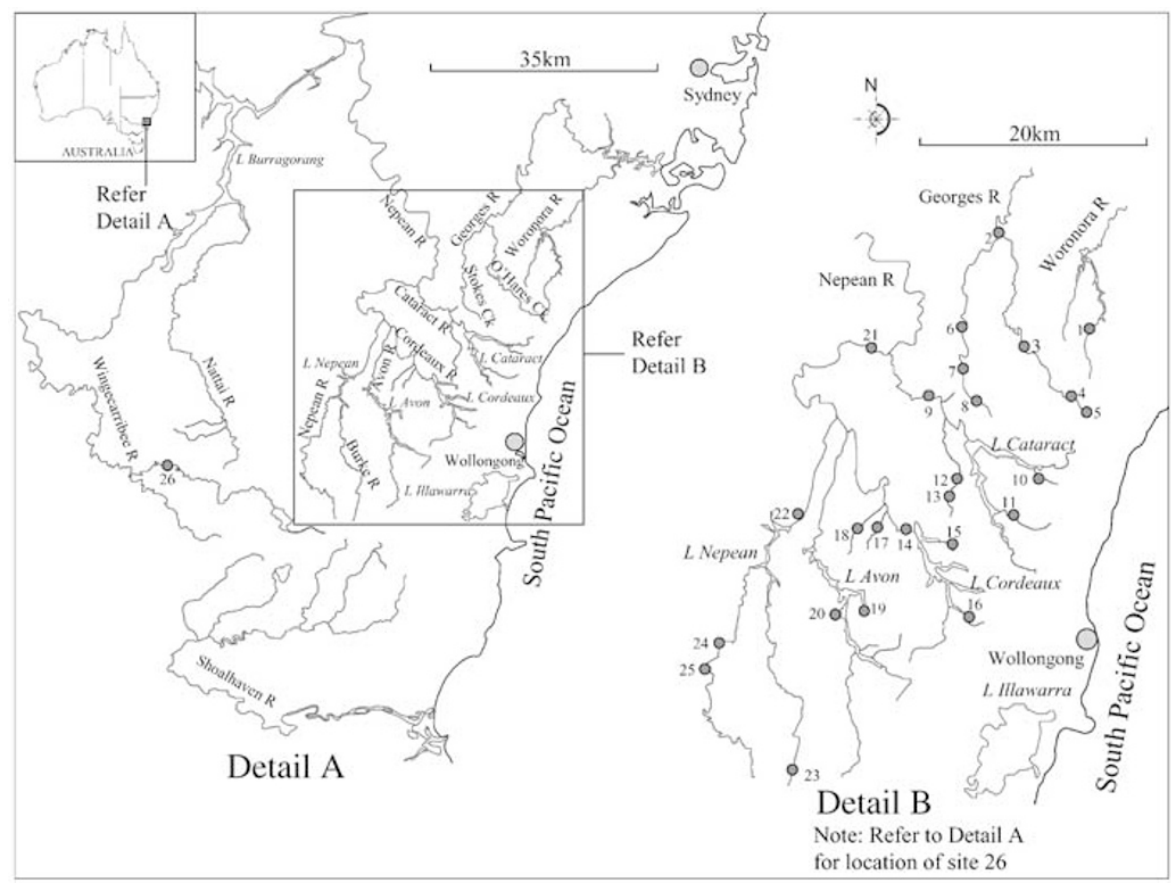

Figure 1 A schematic map of south-eastern New South Wales showing major drainage divisions within the Sydney Water Supply Catchment and locations of the 26 sampling sites. 
through Botany Bay. The Shoalhaven Catchment covers an area of approximately $5700 \mathrm{~km}^{2}$ and drains into the Tasman Sea, east of Nowra (Sydney Catchment Authority, 2002).

In the present study, drainage patterns of river and stream networks were defined at two levels, (a) the catchment, in which the stream network drains through a single outlet into the sea and (b) the subcatchment, for each major river forming a component of the catchment. We adopted a hierarchical sampling design to determine the degree of genetic structuring between catchments as well as among and within subcatchments of each catchment. Within the upper Georges Catchment, two subcatchments were sampled: the Woronora and Georges Rivers. Within the upper Nepean Catchment (the southern reach of the Hawkesbury/Nepean Catchment), five subcatchments were sampled: the Cataract, Cordeaux, Avon, Nepean and Wingecarribee Rivers (Figure 1).

There are six dam impoundments in the study area: the Woronora, Cataract, Cordeaux, Avon, Nepean and Wingecarribee Reservoirs. All of these were built in the last century: Cataract Dam in 1907, Cordeaux Dam in 1926, Avon Dam in 1927, Nepean Dam in 1935, Woronora Dam in 1941 and Wingecarribee Dam in 1974 (Sydney Catchment Authority, 2002). Periodically, water is released below dam impoundments and transfers are made between dams in the Nepean Catchment. We accounted for this in our sampling design by selecting streams above the impoundment for some sites within each subcatchment. Also, as a point of comparison to samples taken from the Nepean Catchment, we sampled intensively in the upper Georges River. The Georges River has not been impounded and has no water regulation transfers with the Nepean Catchment.

There were some geographic gaps in our sampling of upland streams because some areas were difficult to access, and in places such as the Avon River in the Nepean Catchment, we found very few of the study species. We sampled $P$. australiensis over the course of three field trips into the study area between November 2001 and October 2002. Shrimp were captured using a $2 \mathrm{~m}$ long seine net, sorted by hand and then immersed under liquid nitrogen, transferred back to the laboratory and stored at $-80^{\circ} \mathrm{C}$ prior to screening.

\section{Genetic typing}

We isolated mitochondrial DNA from $P$. australiensis muscle tissue using the alkaline lysis DNA extraction protocol outlined by Tamura and Aotsuka (1988). A $710 \mathrm{bp}$ fragment of the cytochrome $c$ oxidase subunit I (COI) mitochondrial gene was amplified using the polymerase chain reaction (PCR) in a $25 \mu$ l total volume

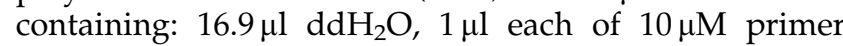
LCO1490 and HCO2198 (Folmer et al, 1994), $0.5 \mu \mathrm{l} 10 \mathrm{mM}$ dNTPs, $1 \mu \mathrm{l} 50 \mathrm{mM} \mathrm{MgCl}_{2}, 2.5 \mu \mathrm{l} 10 \times$ reaction buffer, $0.1 \mu \mathrm{l}$ DNA (Taq) polymerase and $1 \mu \mathrm{l}$ template DNA. PCR was performed on the Geneamp PCR System 9700 (PE Applied Biosystems) with an initial denaturation step of $94^{\circ} \mathrm{C}$ for $5 \mathrm{~min} ; 15$ cycles of $94^{\circ} \mathrm{C}$ for $30 \mathrm{~s}, 40^{\circ} \mathrm{C}$ for $30 \mathrm{~s}, 72^{\circ} \mathrm{C}$ for $1 \mathrm{~min}$; 25 cycles of $94^{\circ} \mathrm{C}$ for $30 \mathrm{~s}, 55^{\circ} \mathrm{C}$ for $30 \mathrm{~s}, 72^{\circ} \mathrm{C}$ for $1 \mathrm{~min}$ and a final extension step of $68^{\circ} \mathrm{C}$ for $5 \mathrm{~min}$.
The DIAGEN horizontal Temperature Gradient Gel Electrophoresis (TGGE) was used to screen amplified PCR products for variation. This electrophoretic technique allows large numbers of individuals to be screened without the resource investment required by direct sequencing. Details of the technique can be found in Hurwood et al (2003). PCR products from individuals representing each unique haplotype were purified using the QIAquick PCR purification kit (Qiagen) and directly sequenced using the LCO1490 and HCO2198 primers, on an Applied Biosystems 377 automated sequencer. Replicate sequencing of each haplotype was performed to confirm that individuals scored by gel as the same haplotype possessed identical DNA sequence. Each sample was sequenced in both directions with overlapping sections, to ensure DNA-strand homology.

\section{Statistical analysis}

COI is a mitochondrial coding gene, so we used Templeton's (1996) contingency test of neutrality prior to genetic analysis. We constructed two-by-two contingency tables for each lineage, splitting intralineage polymorphisms into tip and interior classes for each of the silent and replacement substitutions and analysed them using Fisher's exact test.

Sequences were aligned by eye using BioEdit Version 5.0.9 (Hall, 1999). Exploratory data analysis of sequences was performed using MEGA Version 2.1 (Kumar et al, 2001).

We examined spatial distribution of genetic variation within $P$. australiensis lineages using the analysis of molecular variance (AMOVA; Excoffier et al, 1992) and nested clade analysis (NCA; Templeton et al, 1995). For AMOVA, $\Phi$-statistics were used to estimate population subdivision with hierarchical partitioning: between catchments, among subcatchments within each catchment and among sites within each subcatchment. Tests of significance (at $\alpha=0.05$ ) were conducted using 1000000 permutations of the data in the program ARLEQUIN version 2.000 (Schneider et al, 2000). NCA was used to test the null hypothesis of no association between clades and geographic location. By virtue of its coalescent approach (ie modelling how the most derived haplotypes coalesce with ancestral types, back through time), the NCA can potentially distinguish between recurrent gene flow and historical evolutionary processes (eg population fragmentation and expansion) by mapping geographic distribution of haplotypes within successive temporal clade groupings in the genealogy network. In the NCA, first a network nesting structure is defined. Then the relative (tip or interior) network position, frequency at each site and geographical location (based on latitude/longitude coordinates) for each clade in a nested group are input into the program Geodis (Posada et al, 2000). The program first performs a simple categorical test for geographic association. This test treats each sample location as a categorical variable and permutational tests are implemented in a nested fashion (ie clade types within a nested category versus geographical location; Templeton and Sing, 1993).

The program then incorporates geographical (straightline) distance among sample sites and calculates two parameters: clade distance and nested clade distance (which are then tested for significance at $\alpha=0.05$ using a 
permutational procedure). As described in Templeton et al (1995), clade distance $\left(D_{\mathrm{c}}\right)$ is the average distance of individuals bearing a haplotype from clade A from the calculated geographical centre of that clade, whereas the nested clade distance $\left(D_{n}\right)$ is the average distance of individuals in clade A from the calculated geographical centre of nesting clade B (the next highest nesting level). A $P$-value is output in Geodis for $D_{\mathrm{c}}$ and $D_{\mathrm{n}}$ for each clade within each nesting. If a significant value is recorded $(P<0.05)$, then the null hypothesis is rejected and that clade is deemed significantly associated with geographical location. An inference key (Templeton et al, 1995) (note that a version updated on October 2001 was used in the present study, which is available for download from the Geodis program website) is then used for each significant clade, to make predictions about the distribution and magnitude of $D_{\mathrm{c}}$ and $D_{\mathrm{n}}$ values, using a coalescent (albeit essentially qualitative) approach. In this way, the key attempts to discriminate between the effects of recurrent gene flow and historical processes that may have affected spatial genetic structure. For example, in the case of identifying a pattern of restricted gene flow, one would expect significantly small clade distance $\left(D_{\mathrm{c}}\right)$ in one or more tips, and for tips to be scattered throughout the more geographically widespread range of interior clades (Crandall and Templeton, 1993; Neigel and Avise, 1993; Castelloe and Templeton, 1994). In contrast, a pattern of range expansion could arise if some older (interior) haplotypes are left in the ancestral area, while younger (tip) haplotypes originating from the expanding population are geographically widespread and/or distant from the ancestral types (Templeton et al, 1995).

The program TCS Version 1.13 (Clement et al, 2000) was used to estimate a haplotype network under statistical parsimony as described by Templeton et al (1992). We then superimposed an evolutionary clade hierarchy upon this network using the rules outlined in Templeton et al (1987), Templeton and Sing (1993) and Crandall (1996). Geographical association of clades was assessed using the program Geodis Version 2.0 (Posada et al, 2000). Degenerate clades (ie those containing less than two known haplotypes) were not included in the analysis.

Since $P$. australiensis is aquatic in all stages of its life cycle, we used one-dimensional stream geographic distances. We acknowledge the possibility of dispersal between subcatchments outside of the main stream channel (this has been hypothesised to explain intercatchment haplotype sharing in south-east Queensland P. australiensis by Hurwood et al, 2003). However, since sampled sites within the Georges and Nepean Catchments are connected by predominantly uninterrupted, preferred habitat, we believe that the stream channel is the most likely dispersal route and stream distances are most appropriate for the NCA.

We could not use NCA to measure geographic distribution of haplotypes between catchments because one-dimensional stream distances between the Nepean and Georges Catchments were inordinately large and lowland reaches of each catchment were not sampled. Therefore, we conducted NCA separately for each catchment, and since the cladograms were subsets of the total resolved network for each lineage, the latter was used to help assign interior versus tip status of the nested clades.

\section{Results}

Using Templeton's (1996) contingency test, we found no evidence of significant deviations from neutrality in our genetic data (lineage $\mathrm{A}, P=0.192$; lineage $\mathrm{B}, P=1.000$; lineage $C, P=0.716$ ).

We generated $563 \mathrm{bp}$ of unambiguous sequence describing 30 unique haplotypes (deposited in Genbank under Accession Numbers AY308075-AY308105). There were no insertions or deletions detected in the sequences. In all, 70 sites (12\%) exhibited variation and 52 sites $(9 \%)$ were phylogenetically informative. Of the 52 informative sites, nine $(17 \%)$ were at the first position of the codon and $43(83 \%)$ were at the third position. The transition (Ti) to transversion (Tv) substitution ratio was 3.43:1.

Hypothesised intralineage networks for lineages A, B and $C$ are shown in Figures 2-4. The maximum number of mutational connections between sequence pairs justified by the $95 \%$ Parsimony Criterion was 10 and all intralineage connections fell below this critical threshold.

\section{Spatial genetic structure}

Since we are presently unable to distinguish different Paratya lineages based on morphology, we had no control over the relative abundance and distribution of lineages within our sample. As it happened, lineage A was well represented within the Nepean and Georges Catchments. For lineages B and C, however, in some cases sample sizes were small and sites were separated by relatively large geographic distances (Table 1 and Figure 1).

NCA could not be used to analyse lineage $C$, because (a) in the Georges Catchment, only one site was sampled that contained this lineage, and (b) in the Nepean Catchment only three haplotypes were recovered (Figure 4) and hypothesised pairwise parsimony probabilities in the cladogram in two out of three cases exceeded 0.95 .

The results of AMOVA and NCA for lineages A, B and $C$ are outlined below. Detailed flow charts summarising nested clade distances for each lineage are not shown here, but are available from the authors on request.

\section{Lineages $A, B$ and $C$}

Between catchments: AMOVA of a total of $518 P$. australiensis across 26 sites within the study area revealed significant genetic structuring between catchments for all three lineages (lineage A: $\Phi_{\mathrm{CT}}=0.269, P<0.001$; lineage B: $\Phi_{\mathrm{CT}}=0.402, P<0.001$; lineage $\left.C \Phi_{\mathrm{CT}}=0.655, P<0.001\right)$. For lineages $\mathrm{A}$ and $\mathrm{C}$, no haplotypes were shared between catchments (Figures 2 and 4, respectively), whereas for lineage B, both haplotypes found in the Georges Catchment occurred in the Nepean Catchment (Figure 3).

\section{Lineage A}

Within the Nepean Catchment: AMOVA indicated significant differentiation among subcatchments $\left(\Phi_{\mathrm{CT}}=0.279, P=0.014\right)$ and significant differentiation among sites within subcatchments $(\Phi \mathrm{SC}=0.648$, $P<0.001)$. The majority of genetic variance was explained at the level of localities within (47\%), rather 


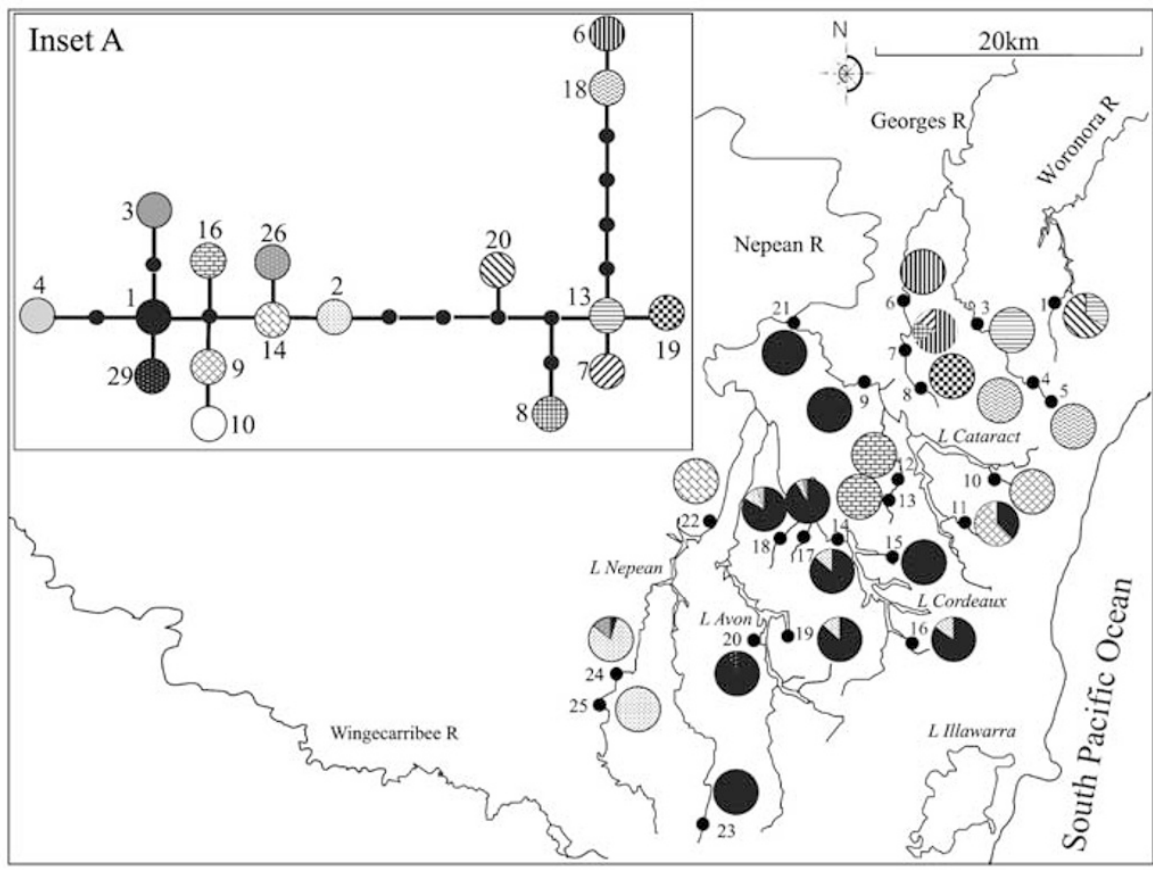

Figure 2 Schematic representation of the study area with pie charts showing frequencies of lineage A haplotypes at each site. Inset (a) shows hypothesised phylogenetic relationships among haplotypes. Haplotype designations correspond to those shown in Table 1 and shadings correspond to those shown in pie charts. Lines between each haplotype indicate a single base change and shaded dots indicate a putative interior node in the network, which was not present in our sample.

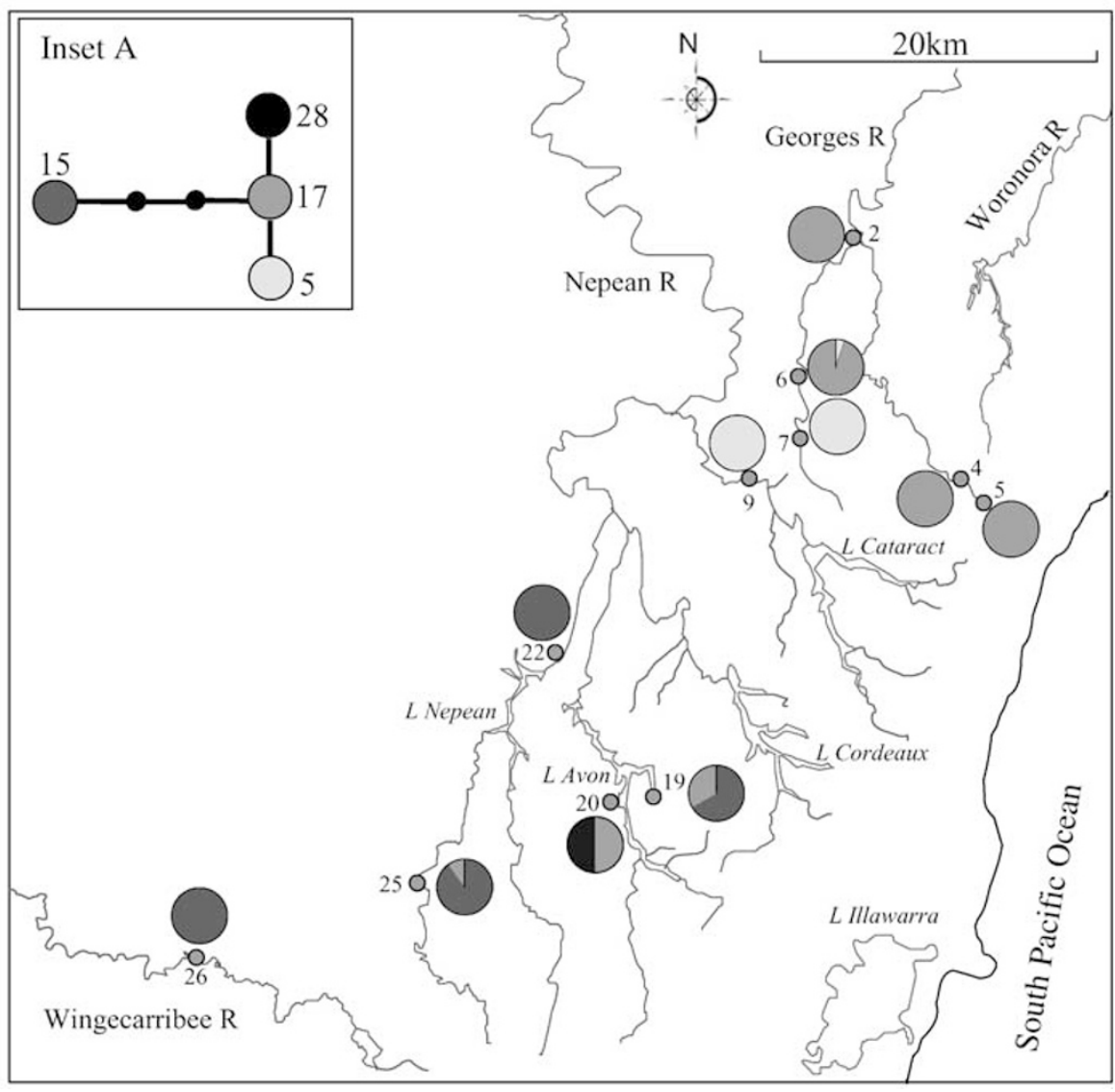

Figure 3 Schematic representation of the study area with pie charts showing frequencies of lineage B haplotypes at each site. Inset (a) shows hypothesised phylogenetic relationships among haplotypes. Haplotype designations correspond to those shown in Table 1 and shadings correspond to those shown in pie charts. Lines between each haplotype indicate a single base change and shaded dots indicate a putative interior node in the network, which was not present in our sample. 


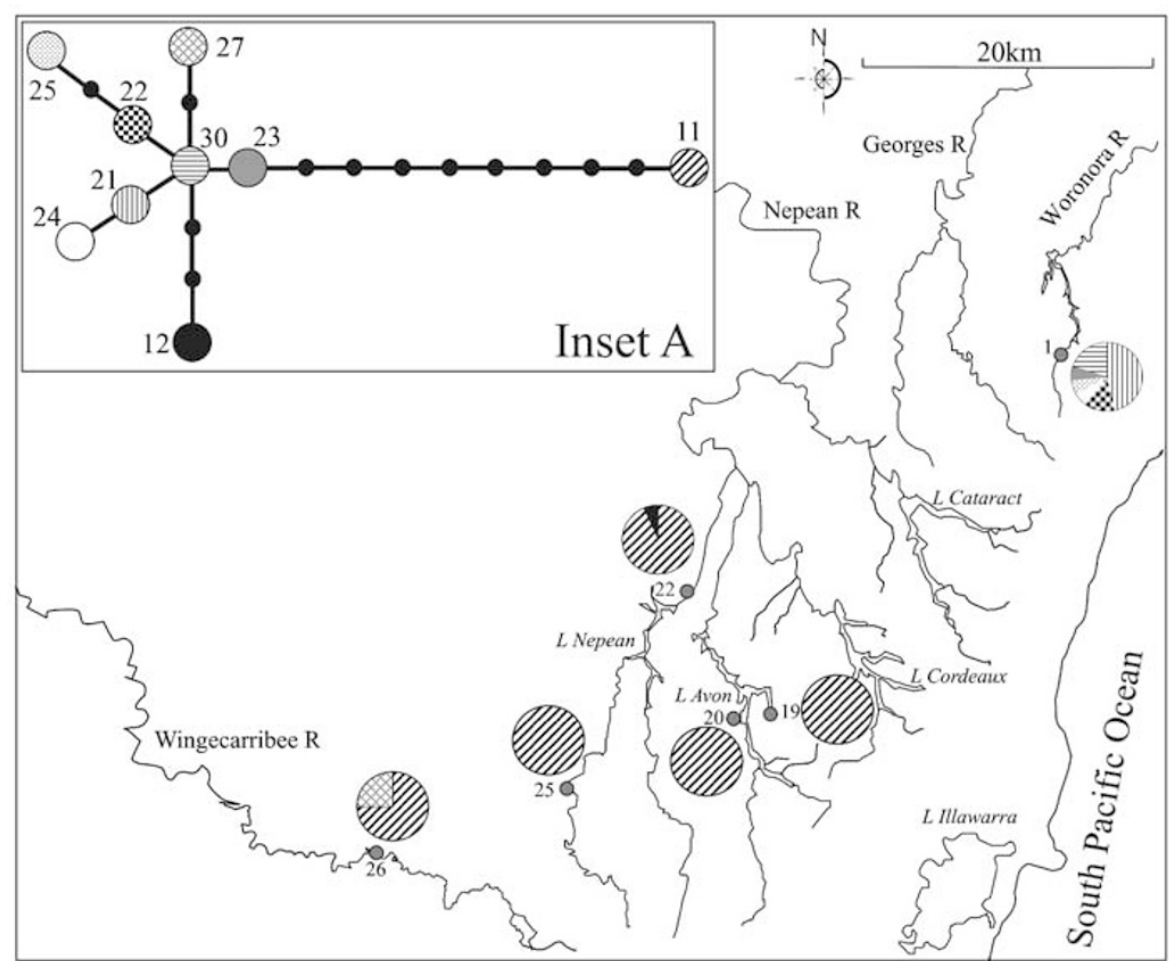

Figure 4 Schematic representation of the study area with pie charts showing frequencies of lineage C haplotypes at each site. Inset (a) shows hypothesised phylogenetic relationships among haplotypes. Haplotype designations correspond to those shown in Table 1 and shadings correspond to those shown in pie charts. Lines between each haplotype indicate a single base change and shaded dots indicate a putative interior node in the network, which was not present in our sample.

than among $(28 \%)$, subcatchments. However, most of the within-subcatchment variation was limited to the Cataract $\quad\left(\Phi_{\mathrm{ST}}=0.777, \quad P<0.001\right) \quad$ and Nepean $\left(\Phi_{\mathrm{ST}}=0.832, P<0.001\right)$ subcatchments. There was no significant differentiation between the Avon and Cordeaux subcatchments $\left(\Phi_{\mathrm{CT}}=-0.017, P=0.905\right)$ or among sites within these sub-catchments $(\Phi \mathrm{SC}=-0.003$, $P=0.482)$.

Based on the $95 \%$ probability of parsimony criterion, 10 unique haplotypes from 262 individuals were partitioned into: three one-step clades, two two-step clades and one three-step clade (Figure 5a). Three of the six clades exhibited significant geographic structuring. Clade 1.6 provided evidence of restricted gene flow, Clade 2.2 long-distance colonisation and Clade 3.1 restricted gene flow/dispersal but with some longdistance dispersal (Table 2).

Within the Georges Catchment: AMOVA indicated no significant differentiation among subcatchments $\left(\Phi_{\mathrm{CT}}=-0.408, P=0.857\right)$. (note that only one site was sampled in the Woronora subcatchment and only six samples were obtained from it; Table 1). There was, however, significant differentiation among sites within the Georges River subcatchment $\left(\Phi_{\mathrm{SC}}=0.899, P<0.001\right)$.

The single Woronora River site was excluded from the NCA due to the large stream distance between subcatchments. Based on the $95 \%$ probability of parsimony criterion, six unique haplotypes from 57 individuals were partitioned into two one-step clades, one two-step clade and one three-step clade (Figure 5b). All the clades exhibited significant geographic structuring. Clade 1.2 provided evidence of long-distance colonisation, Clade 1.3 of contiguous range expansion and Clades 2.1 and 3.1 of restricted gene flow with isolation by distance (Table 2).

\section{Lineage $B$}

Within the Nepean Catchment: AMOVA revealed no significant differentiation among $\left(\Phi_{\mathrm{CT}}=0.753, P=0.133\right)$ or within $\left(\Phi_{\mathrm{SC}}=0.498, P=0.314\right)$ subcatchments. However, there was significant differentiation among all sites $\left(\Phi_{\mathrm{ST}}=0.876, P<0.001\right)$. The absence of significant differentiation among and within subcatchments may be related to low sample size $(N=51)$, since $\Phi_{\mathrm{CT}}$ and $\Phi_{\mathrm{SC}}$ are large, $\Phi_{\mathrm{ST}}$ is large and significant and some haplotypes are geographically restricted to a single site within the catchment (Figure 3).

Based on the $95 \%$ probability of parsimony criterion, four unique haplotypes from 51 individuals were partitioned into one one-step clade and one two-step clade (Figure 5c). Both clades exhibited significant geographic structuring. Clade 1.2 provided evidence of restricted gene flow (with isolation by distance), whereas Clade 2.1 indicated range expansion (long-distance colonisation) (Table 2).

Within the Georges River subcatchment: There was significant differentiation among all sites $\left(\Phi_{\mathrm{ST}}=0.941\right.$, $P<0.001)$. Only two haplotypes were present in our sample. Three sites were fixed for one haplotype (17), one site was fixed for the other (haplotype 5) and one site 
Table 1 Mitochondrial lineage haplotype frequencies for each sampled site

\begin{tabular}{|c|c|c|c|c|c|c|c|c|c|c|c|c|c|c|c|c|c|c|c|c|c|c|c|c|c|c|c|}
\hline $\begin{array}{l}\text { Site Designation } \\
\text { Catchment } \\
\text { Subcatchment } \\
n \\
\text { Haplotype design }\end{array}$ & $\begin{array}{c}1 \\
\text { Ge } \\
\text { WR } \\
21\end{array}$ & $\begin{array}{c}2 \\
\text { Ge } \\
\text { GR } \\
20\end{array}$ & $\begin{array}{c}3 \\
\mathrm{Ge} \\
\mathrm{GR} \\
22\end{array}$ & $\begin{array}{c}4 \\
\text { Ge } \\
\text { GR } \\
19\end{array}$ & $\begin{array}{c}5 \\
\text { Ge } \\
\text { GR } \\
23\end{array}$ & $\begin{array}{c}6 \\
\text { Ge } \\
\text { GR } \\
20\end{array}$ & $\begin{array}{c}7 \\
\text { Ge } \\
\text { GR } \\
22\end{array}$ & $\begin{array}{c}8 \\
\text { Ge } \\
\text { GR } \\
18\end{array}$ & $\begin{array}{c}9 \\
\mathrm{Ne} \\
\mathrm{CAR} \\
20\end{array}$ & $\begin{array}{c}10 \\
\text { Ne } \\
\text { CAR } \\
16\end{array}$ & $\begin{array}{c}11 \\
\mathrm{Ne} \\
\text { CAR } \\
24\end{array}$ & $\begin{array}{c}12 \\
\mathrm{Ne} \\
\mathrm{CAR} \\
21\end{array}$ & $\begin{array}{c}13 \\
\mathrm{Ne} \\
\text { CAR } \\
16\end{array}$ & $\begin{array}{c}14 \\
\mathrm{Ne} \\
\mathrm{COR} \\
22\end{array}$ & $\begin{array}{c}15 \\
\mathrm{Ne} \\
\mathrm{COR} \\
19\end{array}$ & $\begin{array}{c}16 \\
\mathrm{Ne} \\
\mathrm{COR} \\
13\end{array}$ & $\begin{array}{c}17 \\
\mathrm{Ne} \\
\mathrm{COR} \\
23\end{array}$ & $\begin{array}{c}18 \\
\mathrm{Ne} \\
\mathrm{COR} \\
18\end{array}$ & $\begin{array}{c}19 \\
\mathrm{Ne} \\
\mathrm{AR} \\
23\end{array}$ & $\begin{array}{c}20 \\
\mathrm{Ne} \\
\mathrm{AR} \\
18\end{array}$ & $\begin{array}{c}21 \\
\mathrm{Ne} \\
\mathrm{NR} \\
17\end{array}$ & $\begin{array}{c}22 \\
\mathrm{Ne} \\
\mathrm{NR} \\
22\end{array}$ & $\begin{array}{c}23 \\
\mathrm{Ne} \\
\mathrm{NR} \\
17\end{array}$ & $\begin{array}{c}24 \\
\mathrm{Ne} \\
\mathrm{NR} \\
21\end{array}$ & $\begin{array}{c}25 \\
\mathrm{Ne} \\
\mathrm{NR} \\
22\end{array}$ & $\begin{array}{c}26 \\
\mathrm{Ne} \\
\text { WIR } \\
21\end{array}$ & Lineage totals \\
\hline \multicolumn{28}{|c|}{ Lineage A 17 haplotypes } \\
\hline 1 & & & & & & & & & 1 & & 9 & & & 19 & 19 & 11 & 21 & 15 & 13 & 13 & 17 & & 17 & 1 & & & \\
\hline 2 & & & & & & & & & & & & & & 3 & & 2 & 1 & 2 & 2 & & & & & 17 & 2 & & \\
\hline 3 & & & & & & & & & & & & & & & & & 1 & & & & & & & & & & \\
\hline 4 & & & & & & & & & & & & & & & & & & 1 & & & & & & & & & \\
\hline 6 & & & & & & 1 & 4 & & & & & & & & & & & & & & & & & & & & \\
\hline $\begin{array}{l}7 \\
8\end{array}$ & & & & & & & 1 & & & & & & & & & & & & & & & & & & & & \\
\hline $\begin{array}{l}8 \\
9\end{array}$ & & & & & & & 1 & & & 16 & 14 & & & & & & & & & & & & & & & & \\
\hline 10 & & & & & & & & & & & 1 & & & & & & & & & & & & & & & & \\
\hline 13 & 2 & & 22 & & & & & & & & & & & & & & & & & & & & & & & & \\
\hline 14 & & & & & & & & & & & & & & & & & & & & & & 3 & & & & & \\
\hline 16 & & & & & & & & & & & & 21 & 16 & & & & & & & & & & & & & & \\
\hline 18 & & & & 4 & 6 & & & & & & & & & & & & & & & & & & & & & & \\
\hline 19 & & & & & & & & 18 & & & & & & & & & & & & & & & & & & & \\
\hline $\begin{array}{l}20 \\
26\end{array}$ & 4 & & & & & & & & & & & & & & & & & & & & & & & & & & \\
\hline $\begin{array}{l}26 \\
29\end{array}$ & & & & & & & & & & & & & & & & & & & & & & & & 3 & & & \\
\hline $\begin{array}{l}29 \\
\text { Total }\end{array}$ & 6 & & 22 & 4 & 6 & 1 & 6 & 18 & 1 & 16 & 24 & 21 & 16 & 22 & 19 & 13 & 23 & 18 & 15 & $\begin{array}{r}1 \\
14\end{array}$ & 17 & 3 & 17 & 21 & 2 & & 325 \\
\hline \multicolumn{28}{|c|}{ Lineage B four haplotypes } \\
\hline 5 & & & & & & 1 & 16 & & 19 & & & & & & & & & & & & & & & & & & \\
\hline 15 & & & & & & & & & & & & & & & & & & & 2 & & & 4 & & & 9 & 13 & \\
\hline 17 & & 20 & & 15 & 17 & 18 & & & & & & & & & & & & & 1 & 1 & & & & & 1 & & \\
\hline 28 & & & & & & & & & & & & & & & & & & & & 1 & & & & & & & \\
\hline Total & & 20 & & 15 & 17 & 19 & 16 & & 19 & & & & & & & & & & 3 & 2 & & 4 & & & 10 & 13 & 138 \\
\hline \multicolumn{28}{|c|}{ Lineage $C$ nine haplotypes } \\
\hline 11 & & & & & & & & & & & & & & & & & & & 5 & 2 & & 14 & & & 10 & 6 & \\
\hline 12 & & & & & & & & & & & & & & & & & & & & & & 1 & & & & & \\
\hline 21 & 7 & & & & & & & & & & & & & & & & & & & & & & & & & & \\
\hline 22 & 2 & & & & & & & & & & & & & & & & & & & & & & & & & & \\
\hline 23 & 1 & & & & & & & & & & & & & & & & & & & & & & & & & & \\
\hline 24 & 1 & & & & & & & & & & & & & & & & & & & & & & & & & & \\
\hline 25 & 1 & & & & & & & & & & & & & & & & & & & & & & & & & & \\
\hline 27 & & & & & & & & & & & & & & & & & & & & & & & & & & 2 & \\
\hline 30 & 3 & & & & & & & & & & & & & & & & & & & & & & & & & & \\
\hline Total & 15 & & & & & & & & & & & & & & & & & & 5 & 2 & & 15 & & & 10 & 8 & 55 \\
\hline & & & & & & & & & & & & & & & & & & & & & & & & & Gran & $=518$ & \\
\hline
\end{tabular}

Ge, Georges; Ne, Nepean; WR, Woronora River; GR, Georges River; CAR, Cataract River; COR, Cordeaux River; AR, Avon River; NR, Nepean River; WIR, Wingecarribee River. 
a

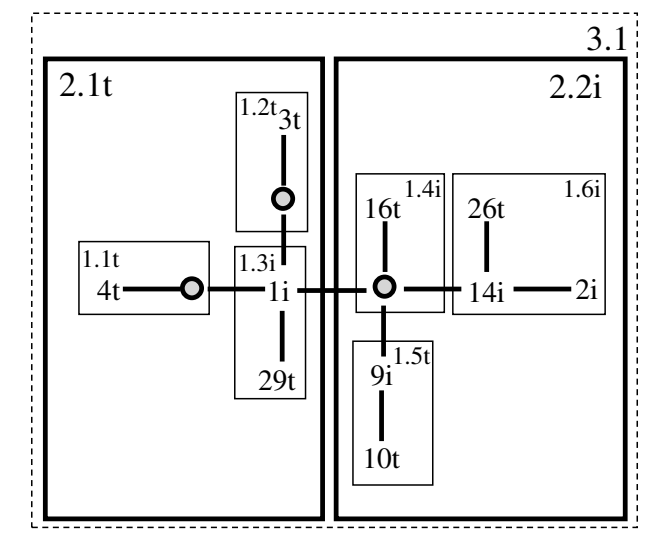

C

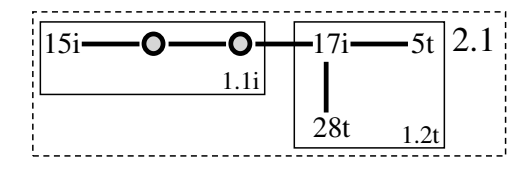

d

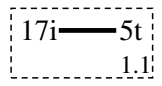

b

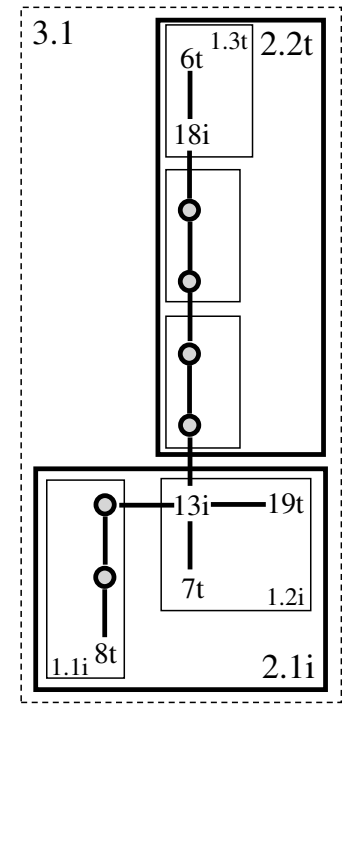

Figure 5 Cladogram nestings for lineage A sampled from (a) the Nepean Catchment and (b) the Georges Catchment and for lineage B sampled from (c) the Nepean Catchment and (d) the Georges Catchment. Thin-line boxes enclose one-step clades, thick-line boxes enclose two-step clades and the dotted box encloses the entire cladogram. The clade step delineation is shown in a corner of each box. Hypothetical haplotypes are represented by a shaded circle. For each lineage, tip (t) or interior (i) status is indicated following the designation for each clade/haplotype. Note that haplotype 15 in lineage B is designated an internal position in our network since a more derived haplotype (not shown) was sampled from the Shoalhaven Catchment by Cook et al (in review).

Table 2 Summary of analyses identifying spatial distribution of genetic variation within three lineages of $P$. australiensis occurring in the study area (only comparisons significant at $P=0.05$ are shown)

\begin{tabular}{|c|c|c|c|}
\hline Lineage & Method of analysis & Geographic region/Clade & Inference \\
\hline \multirow[t]{11}{*}{ A } & AMOVA & NC versus GC & Restricted gene flow between catchments \\
\hline & AMOVA & NC & Restricted gene flow among subcatchments \\
\hline & AMOVA & Cataract and Nepean & Restricted local gene flow within Cataract and Nepean subcatchments \\
\hline & NCA & NC/Clade 1.6 & IBD among Cordeaux/Avon/Nepean subcatchments \\
\hline & & Clade 2.2 & LDC within Nepean Catchment \\
\hline & & Clade 3.1 & LDD within Nepean Catchment \\
\hline & AMOVA & GC ( $\Phi_{\mathrm{SC}}$ only $)$ & Restricted gene flow within Georges River subcatchment \\
\hline & NCA & GR/Clade 1.2 & LDC within Georges River subcatchment \\
\hline & & Clade 1.3 & RE within Georges River subcatchment \\
\hline & & Clade 2.1 & IBD within Georges River subcatchment \\
\hline & & Clade 3.1 & IBD within Georges River subcatchment \\
\hline \multirow[t]{5}{*}{ B } & AMOVA & NC versus GC & Restricted gene flow between catchments \\
\hline & NCA & NC/Clade 1.2 & IBD between Cataract/Avon/Nepean subcatchments \\
\hline & & Clade 2.1 & LDC within Nepean Catchment \\
\hline & AMOVA & GR & Restricted gene flow within Georges River subcatchment \\
\hline & NCA & GR/Clade 1.1 & Range expansion or restricted gene flow \\
\hline $\mathrm{C}$ & AMOVA & $\mathrm{NC}$ versus $\mathrm{GC}$ & Restricted gene flow between catchments \\
\hline
\end{tabular}

NC, Nepean Catchment; GC, Georges Catchment; GR, Georges River; LDC, range expansion of populations through long-distance colonisation; LDD, recurrent gene flow with some long-distance dispersal; RE, range expansion of populations to geographically contiguous areas; IBD, recurrent gene flow restricted by isolation by distance.

shared the two haplotypes, although in unequal frequencies (Figure 3).

Based on the $95 \%$ probability of parsimony criterion, the two unique haplotypes from 87 individuals were partitioned into a single clade for the nested analysis, which exhibited significant geographic structuring and suggested either range expansion or restricted gene flow (Figure 5d, Table 2).

\section{Lineage $\mathrm{C}$}

Within the Nepean Catchment, there was no significant differentiation among $\left(\Phi_{\mathrm{CT}}=0.202, . P=0.133\right)$ or within 
( $\Phi$ SC $=-0.055, \quad P=0.232) \quad$ subcatchments. Only three haplotypes (11, 12 and 27) were found in the catchment, with $93 \%(37 / 40)$ of individuals bearing haplotype 11 (Figure 4). The large (but nonsignificant) $\Phi_{\mathrm{CT}}$ value is primarily a result of $(2.2 \%)$ divergence between haplotypes 11 and $12 / 27$.

Within the Georges Catchment, the single site in the Woronora River exhibited a high diversity of haplotypes (Figure 4).

\section{Discussion}

\section{Overall patterns of genetic structuring}

We found significant spatial structuring of genetic variation between and within catchments in Paratya australiensis lineages A and B. Hurwood et al (2003) reported the presence of lineages $\mathrm{B}$ and $\mathrm{E}$, P. australiensis, and significant population structuring between and within catchments, in south-east Queensland. Taken together, therefore, these data suggest a general pattern of restricted gene flow among upland populations of $P$. australiensis.

A number of studies on decapod crustaceans have reported the extent of population genetic structuring to be closely associated with hydrography. For example, in marine environments, penaeid shrimps tend to exhibit a lack of genetic structuring (Mulley and Latter, 1981; Weber et al, 1993) and in cases of notable genetic differentiation, most of the structure is often associated with sites hundreds to thousands of kilometres apart (eg Penaeus monodon; Benzie et al, 1993). Such shallow genetic structuring is typically associated with extensive larval and adult drift on prevailing currents. In the freshwater catchments of western Queensland, Australia both the prawn, Macrobrachium australiense (Cook et al, 2002), and the crayfish, Cherax destructor (Hughes and Hillyer, 2003), exhibited signatures of high gene flow within catchment divisions, across hundreds of kilometres. In these cases, limited structuring was associated with the low topographical relief and minimised channel structuring of the system. Similarly, the freshwater shrimp, Caridina sp. (Woolschot et al, 1999) exhibited minimal genetic structuring in lowland coastal stream catchments of south-east Queensland. In contrast, however, studies of the freshwater shrimp Caridina zebra in rainforest streams of the Tully River Catchment north-east Queensland have shown gene flow to be highly restricted, most likely in association with dramatic architectural structuring and changes in the stream profile, such as waterfalls and cascades (Hughes et al, 1996; Hurwood and Hughes, 2001).

Similarly, in the present study, abrupt altitudinal shifts in stream architecture through escarpments and confluences and irregular planform at headwaters (Department of Land and Water Conservation, 2001) are likely to have restricted recent historical and current gene flow processes, resulting in the significant population structuring observed in $P$. australiensis. Changes in stream profile may also act as a barrier to dispersal of $P$. australiensis in some parts of the Conondale Range (Hurwood et al, 2003), and it is plausible that dispersal behaviour exhibited by $P$. australiensis occurring in upland streams throughout south-east Australia will prove closely linked to the extent of architectural structuring of the stream channel.
In regions where dispersal of $P$. australiensis is less restricted by in-stream barriers and geomorphology, we could expect populations to be less structured. Investigations are underway to determine if $P$. australiensis lineages inhabiting both upland and lowland river drainages elsewhere in south-east Australia exhibit genetic signatures of restricted dispersal similar to shown in the present study.

The present data indicated no spatial genetic structuring within lineage C P. australiensis, but more detailed sampling is required to determine whether the recovered pattern of gene flow is due to better dispersal capabilities in this lineage or stochasticity associated with limited sampling.

Observational data (Hancock and Bunn, 1999) suggest that dispersal capabilities in lineage E P. australiensis from the Conondale Range will be similar for males and females (Hurwood et al, 2003). The patterns of femalemediated dispersal inferred from our mitochondrial data may therefore be generally representative of male dispersal capabilities in the lineages investigated in the present study. Comparative analysis using nuclear markers would allow this hypothesis to be tested.

\section{Genetic structuring between catchments}

Notable intralineage divergence and absence of haplotype sharing between the Nepean and Georges Catchments in lineages $\mathrm{A}$ and $\mathrm{C}$ are suggestive of population fragmentation, perhaps associated with the ongoing aridity characteristic of the later Pleistocene glacial cycles (Kershaw and Nanson, 1993). However, another possibility is that this pattern arose under recurrent gene flow (isolation by distance), since intermediate populations, which undoubtedly occur in lowland sites within each drainage, were not sampled. Interestingly, the signature of fragmentation is less apparent in lineage B, where an ancestral haplotype (17) has been retained in both catchments (albeit in low frequency in the Nepean). This could be explained by (a) different rates of COI evolution among the identified lineages, resulting in more pronounced ancestral retention in lineage $\mathrm{B}$ than lineages $\mathrm{A}$ or C, (b) different dispersal characteristics among lineages and/or (c) stochastic variation arising from incomplete sampling.

In lineage B, a tip haplotype (5) was shared between catchments (across the Georges and Cataract Rivers; Figure 3). If this indeed represents recent gene flow across the catchment boundary, rather than a northward colonisation event from within the Nepean Catchment, it may be the result of either flooding (since catchment stream headwaters are as close as $100 \mathrm{~m}$ in this area and floodplain pockets may be occasionally inundated) and / or terrestrial dispersal. Intercatchment sharing of mitochondrial haplotypes has also been observed in Conondale Range populations of $P$. australiensis by Hurwood et al (2003) and north-east Queensland populations of another atyid shrimp (Caridina zebra) by Hurwood and Hughes (2001), and terrestrial dispersal was proposed as a possible explanation in both cases.

\section{Genetic structuring within catchments}

Patterns of restricted gene flow: For lineages A and B, both AMOVA and NCA indicated significant spatial structuring of genetic variation within the Nepean and 
Georges Catchments. In the case of lineage B, however, NCA specified spatial genetic structuring in the Nepean Catchment at both nesting levels in the hierarchy, whereas AMOVA recovered no association with a priori subcatchment groupings (only the overall $\Phi_{\mathrm{ST}}$ was significant). These data highlight a fundamental difference between the two analyses: AMOVA requires a priori geographic partitioning of the region under study that may be inappropriate for discerning spatial variation at higher nesting levels in the hierarchy, whereas NCA produces a hierarchy from the genetic data via an objective criterion and can potentially localise factors influencing spatial structuring of genetic variation, both geographically and temporally (Templeton, 1998).

Thus, recurrent (relative to the mutation rate of the locus) but restricted gene flow has apparently pervaded the evolution of lineages A and B in both catchments; however, episodic historical expansion events (contiguous/long-distance colonisations) may also be overlaid upon this framework (see Table 2). For example, in lineage $\mathrm{A}$ the range expansion (long-distance colonisation) detected within Clade 2.2 involves all four subcatchments in the Nepean Catchment and this is in turn nested within a range expansion at the highest clade level, involving expansion within all four subcatchments. As these two events are superimposed both geographically and within the cladogram nesting, we assume that the range expansion occurred gradually on the time scale marked by coalescent events within this gene (Templeton, 1998), and was likely the result of separate episodes of colonisation within different parts of the study area.

Patterns of homogenising gene flow: For a number of lineage A clades in the NCA, there was no significant geographical association of haplotypes. Two common haplotypes ( 1 and 2 ) were shared widely among sites throughout the Nepean Catchment (Figure 2), and this was particularly evident in the Cordeaux and Avon Rivers, where AMOVA revealed no pattern of spatial structuring among or within subcatchments. Similar patterns of haplotype sharing were observed within and between catchments for lineage B (haplotypes 15 and 17, respectively) and within the Nepean Catchment for Lineage C (haplotype 11) (Figures 3 and 4).

In lineages $\mathrm{A}$ and $\mathrm{B}$, all the widely shared haplotypes occupied an internal (ancestral) position in the network. Given that sample sizes for lineage $C$ were small and from few sites, it seems plausible that the common and widespread haplotype 11 (identified in the present study as a tip) is also in fact, ancestral and that rarer, more derived haplotypes are missing from our sample. For all three lineages therefore, the identified gene flow patterns could be explained if recent historical flooding has facilitated episodic colonisation events in parts of the study area. This hypothesis is supported by (a) evidence of periodic flooding (every 1-20 years) throughout the Nepean Catchment (Department of Land and Water Conservation, 2001) and (b) palaeoflood analysis which predicted that at least one flood occurring in the study area during the late Holocene was more than eight metres higher than the recorded maximum (Saynor and Erskine, 1993).

However, current land use, as well as recent historical land management practices, will potentially have affected present-day distribution of $P$. australiensis lineages occurring in the study area. In addition to environmental flows and riparian releases, a system of pipelines, pumps, tunnels and canals periodically transfers water from storage points to water filtration plants in parts of the SWSC. It is therefore conceivable that widespread distribution of some haplotypes may have been at least partly facilitated by human-mediated dispersal via water transfers between impoundments and periodic dam outflows in the last 100 years. Certainly, because of ancestral retention and both widespread distribution and high relative frequency of ancestral types, individuals bearing those haplotypes would be the most likely to be dispersed, whereas rarer, derived haplotypes may remain largely geographically restricted.

However, our genetic data implied range expansion events within parts of the Georges River for both lineages $A$ and $B$, and homogenising gene flow across the Georges/Nepean Catchment boundary for lineage B. These patterns cannot be attributed to water transfers, since the Georges River is unregulated and there are no transfers between the two catchments.

Moreover, the increased potential of dispersal (via water transfers) serves only to emphasise the overall pattern of restricted gene flow detected in $P$. australiensis lineages $\mathrm{A}$ and $\mathrm{B}$ occurring in regulated (Nepean Catchment) stream channels. The patterns of isolation by distance detected by the NCA within lineages A and B in the Nepean Catchment would seem less likely to arise by human-mediated dispersal than natural processes. This suggests that generally $P$. australiensis is not being moved among subcatchments during periodic water transfers.

In the future, there are plans to augment sources of water supply to Sydney by constructing new dams or enlarging/upgrading existing ones. Also, a commercial coal seam lies beneath the upper Nepean Catchment and mining operations produce subsidence and will potentially alter drainage patterns and flow regimes within the catchment. Predictions relating to demographic and land use changes in the study area (Sydney Catchment Authority, 2002) highlight the need to consider strategies relating to catchment management and infrastructure works carefully.

Genetic analysis of samples collected thus far from south-eastern Australia suggests that two lineages (A and D) of $P$. australiensis, which may represent young species, are endemic to the SWSC (Cook et al, in review). The recolonisation ability of these taxa in upland streams of the SWSC as a whole must be considered poor. Our results suggest that if certain populations of $P$. australiensis are extirpated as a result of future environmental disturbance, they may either (a) contain geographically restricted lineages that will be sent extinct and/or (b) not be recolonised by local populations, due to limited dispersal and gene flow.

\section{Acknowledgements}

We thank James Fawcett, Mia Hillyer, Tim Page, Jemma Somerville and Brooke Steenstra for help with sampling and laboratory work. Simon Williams and Amanda Kotlash provided expert knowledge of stream access points, within the study area. We also thank Rod 
Eastwood for insightful discussion with regard to nested clade analysis and Stephanie Woodbridge for help with the figures. Stuart Bunn made helpful comments on an earlier draft of the manuscript. This study forms part of a larger project on connectivity among populations of stream fauna, funded by the Cooperative Research Centre for Freshwater Ecology.

\section{References}

Benzie JAH, Ballment E, Frusher S (1993). Genetic structure of Penaeus monodon in Australia: concordant results from mtDNA and allozymes. Aquaculture 111: 89-94.

Castelloe J, Templeton AR (1994). Root probabilities for Intraspecific gene trees under neutral coalescent theory. Mol Phylog Evol 3: 102-113.

Clement M, Posada D, Crandall KA (2000). TCS: a computer program to estimate gene genealogies. Mol Ecol 9: 1657-1659.

Cook BD, Baker AM, Hurwood DA, Hughes JM. Mitochondrial DNA suggests cryptic species in an atyid shrimp (Paratya australiensis). Freshwater Biol (in review).

Cook B, Hughes JM, Bunn SE (2002). Population structure of the freshwater prawn Macrobrachium australiense in drainages of western Queensland, Australia. Freshwater Biol 12: 2098-2112.

Crandall KA (1996). Multiple interspecies transmissions of human and simian T-cell leukemia/lymphoma virus type I sequences. Mol Biol Evol 13: 115-131.

Crandall KA, Templeton AR (1993). Empirical tests of some predictions from coalescent theory with applications to intraspecific phylogeny reconstruction. Genetics 134: 959-969.

Department of Land and Water Conservation (2001). Geomorphic Categorisation of Streams in the Hawkesbury Nepean Catchment. DLWC: NSW, Australia.

Excoffier L, Smouse PE, Quattro J (1992). Analysis of molecular variance inferred from metric distances among DNA haplotypes: application to human mitochondrial DNA restriction data. Genetics 131: 479-491.

Folmer O, Black M, Hoeh W, Lutz R, Vrijenhoek R (1994). DNA primers for amplification of mitochondrial cytochrome $c$ oxidase subunit I from diverse metazoan invertebrates. Mol Mar Biol Biotechnol 3: 294-299.

Hall TA (1999). BioEdit: a user-friendly biological sequence alignment editor and analysis program for Windows 95/98/ NT. Nucl Acids Symp Ser 41: 95-98.

Hancock MA, Bunn SE (1999). Swimming response to water current in Paratya australiensis Kemp, 1917 (Decapoda: Atyidae) under laboratory conditions. Crustaceana 72: 313-323.

Hughes JM, Hillyer MJ (2003). Patterns of connectivity among populations of Cherax destructor (Decapoda: Parastacidae) in western Queensland, Australia. Mar Freshwater Res 54: $1-10$.

Hughes JM, Bunn SE, Hurwood DA, Choy S, Pearson RG (1996). Genetic differentiation among populations of Caridina zebra (Decapoda: Atyidae) in tropical rainforest streams, northern Australia. Freshwater Biol 36: 289-296.

Hughes JM, Bunn SE, Hurwood DA, Cleary C (1998). Dispersal and recruitment of Tasiagma ciliata (Trichoptera: Tasmiidae) in rainforest streams, southeast Queensland, Australia. Freshwater Biol 41: 1-10.

Hughes JM, Bunn SE, Kingston M, Hurwood DA (1995). Genetic differentiation and dispersal among populations of Paratya australiensis (Atyidae) in rainforest streams in southeast Queensland, Australia. J N Am Benthol Soc 14: 158-173.

Hughes JM, Goudkamp K, Hurwood D, Hancock M, Bunn SE (2003). Translocation causes extinction of a local population of the freshwater shrimp Paratya australiensis (Atyidae). Cons Biol 17: 1007-1013.

Hurwood DA, Hughes JM (1998). Phylogeography of the freshwater fish, Mogurnda adspersa, in streams of northeastern
Queensland, Australia: Evidence for altered drainage patterns. Mol Ecol 7: 1507-1517.

Hurwood DA, Hughes JM (2001). Nested clade analysis of the freshwater shrimp, Caridina zebra (Decapoda: Atyidae), from north-eastern Australia. Mol Ecol 10: 113-125.

Hurwood DA, Hughes JM, Bunn SE, Cleary C (2003). Population structure in the freshwater shrimp (Paratya australiensis) inferred from allozymes and mitochondrial DNA. Heredity 90: 64-70.

Kershaw AP, Nanson GC (1993). The last full glacial cycle in the Australian region. Glob Plan Change 7: 1-9.

Kumar S, Tamura T, Jakobsen IB, Nei M (2001). MEGA2: molecular evolutionary genetics analysis software. Bioinformatics 17: 1244-1245.

McGlashan DJ, Hughes JM (2001). Low levels of mitochondrial DNA and allozyme variation among populations of freshwater fish Hypseleotris compressa (Gobiidae: Eleotridinae): implications for its biology, populations connectivity and history. Heredity 86: 222-233.

McGlashan DJ, Hughes JM, Bunn SE (2001). Within drainage population genetic structure of the freshwater fish Pseudomugil signifier (Pseudomugilidae) in northern Australia. Can J Fish Aquat Sci 58: 1842-1852.

Meffe GK, Vrijenhoek RC (1988). Conservation genetics in the management of desert fishes. Cons Biol 2: 157-167.

Miller MP, Blinn DW, Keim P (2002). Correlations between observed dispersal capabilities and patterns of genetic differentiation in populations of four aquatic insect species from the Arizona White Mountains, USA. Freshwater Biol 47: $1660-1673$

Mulley JC, Latter BDH (1981). Geographic differentiation of tropical Australian penaeid prawn populations. Aust J Mar Freshwater Res 32: 886-906.

Neigel JE, Avise JC (1993). Application of a random-walk model to geographic distributions of animal mitochondrial DNA variation. Genetics 135: 1209-1220.

Posada D, Crandall KA, Templeton AR (2000). GEODIS: a program for the cladistic nested analysis of the geographical distribution of genetic haplotypes. Mol Ecol 9: 487-488.

Saynor MJ, Erskine WD (1993). Characteristics and implications of high-level slackwater deposits in the Fairlight Gorge, Nepean River, Australia. Aust J Mar Freshwater Res 44: 735-747.

Schmidt SK, Hughes JM, Bunn SE (1995). Gene flow among conspecific populations of Baetis sp. (Ephemeroptera): adult flight and larval drift. J N Am Benthol Soc 14: 147-157.

Schneider S, Roessli D, Excoffier L (2000). Arlequin Ver. 2.000: A Software for Population Genetics Data Analysis. Genetics and Biometry Laboratory, University of Geneva: Switzerland.

Sydney Catchment Authority (2002). Draft Bulk Water Network Delivery Plan. Bulk Water Division: Sydney, Australia.

Tamura K, Aotsuka T (1988). Rapid isolation method of animal mitochondrial DNA by the alkaline lysis procedure. Biochem Genet 26: 815-819.

Templeton AR (1996). Contingency tests of neutrality using intra/interspecific gene trees: the rejection of neutrality for the evolution of the mitochondrial cytochrome oxidase II gene in the hominoid primates. Genetics 144: 1263-1270.

Templeton AR (1998). Nested clade analysis of phylogeographic data: testing hypotheses about gene flow and population history. Mol Ecol 7: 381-397.

Templeton AR, Sing CF (1993). A cladistic analysis of phenotypic associations with haplotypes inferred from restriction endonuclease mapping. IV. Nested analyses with cladogram uncertainty and recombination. Genetics 134: 659-669.

Templeton AR, Boerwinkle E, Sing CF (1987). A cladistic analysis of phenotypic associations with haplotypes inferred from restriction endonuclease mapping. I. Basic theory and an analysis of alcohol dehydrogenase activity in Drosophila. Genetics 117: 343-351. 
Templeton AR, Crandall KA, Sing CF (1992). A cladistic analysis of phenotypic associations with haplotypes inferred from restriction endonuclease mapping and DNA sequence data. III. Cladogram estimation. Genetics 132: 619-633.

Templeton AR, Routman E, Phillips C (1995). Separating population structure from population history: a cladistic analysis of the geographic distribution of mitochondrial DNA haplotypes in the Tiger salamander, Ambystoma tigrinum. Genetics 140: 767-782.

Walsh CJ (1993). Laraval development of Paratya australiensis Kemp, 1917 (Decapoda: Caridea: Atyidae) reared in the laboratory, with comparisons of fecundity and egg and larval size between estuarine and riverine environments. J Crust Biol 13: 456-480.

Walsh CJ, Mitchell BD (1995). The freshwater shrimp Paratya australiensis (Kemp, 1917) (Decapoda: Atyidae) in estuaries of south-western Victoria, Australia. Mar Freshwater Res 46: 959-965.

Williams WD (1977). Some aspects of the ecology of Paratya australiensis (Crustacea: Decapoda: Atyidae). Aust J Mar Freshwater Res 28: 403-415.

Wishart M, Hughes JM (2003). Genetic population structure of the net-winged midge, Elporia barnardi (Diptera: Blephariceridae) in streams of the south-western Cape, South Africa: implications for dispersal. Freshwater Biol 48: 28-38.

Weber LI, Conceico MB, Ruffino ML, Levy JA (1993). Population genetics of the shrimp Artemesia longinaris (Crustacea, Penaeidae) on the Southwest Atlantic coast. Comp Biochem Physiol B 106: 1015-1020.

Woolschot L, Hughes JM, Bunn SE (1999). Dispersal among populations of Caridina sp.: Decapoda: Atyidae) in coastal lowland streams, south-eastern Queensland, Australia. Mar Freshwater Res 50: 681-688. 